\section{Kalinichenko $\mathbf{N}$.}

\title{
EXPERIMENTAL STUDIES OF THE GRINDING PROCESS BY PLANETARY GRINDING HEAD
}

Об'єктом дослідження є процес глибинного шліфування деталей авіаційних двигунів із важкооброблюваних матеріалів. В авіаційній галузі з таких матеріалів (сталь 4Х5МФ1С, ХН5ЗКВМТЮБ та ін.) виробляють лопатки та диски турбін, сегменти соплових апаратів, сектори вхідих направляючих апаратів, плунжери, порині, зубчаті колеса і т. д. Лезові методи оброблення не є дуже ефективними при створенні подібних деталей. Підвищений знос технологічного обладнання, інструменту призводить до росту температури у зоні різання, що негативно впливає на показники якості $і$ знижує ресурс виробу в цілому. Постійне заточення, правлення або зміна інструменту на новий, додаткове налаштування технологічного обладнання призводить до збільшення собівартості виготовлення деталей з важкооброблюваних матеріалів. Впровадження глибинного шліфування у технологічні процеси дозволяє уникнути зазначених вище негативних факторів. Збільшення технологічних режимів шліфування знижує час оброблення, але стає причиною виникнення в поверхневих шарах припікань і пошкодження оброблюваної поверхні. Експериментальні дослідження проиесу глибинного шліфування проводили з метою визначення температур у підповерхневих шарах деталі в процесі ї̈ оброблення і подальшого порівняння з теоретично отриманими результатами розробленоі математичної моделі. Оброблення виконували на плоскошліфувальному верстаті Jotes SPD-30b (Польща). Температуру замірювали контактним методом (вимірювачем ОВЕН МBA 8, Росія) і безконтактним (пірометром СТ 3М, Німеччина). Результати отриманих експериментальних значень температур наведені у вигляді таблиць. За результатами виконаних досліджень було встановлено, що застосування планетарної шліфувальної головки для технології глибинного шліфування деталей машинобудівної і авіаційної галузей з важкооброблюваних, корозійностійких матеріалів приводить до зниження енергосилових показників процесу. Крім иьвого спостерігається поліпшення класу чистоти поверхні (шорсткість оброблюваних поверхонь Ra знаходиться в межах 1,25-1,8 мкм). Отримані результати свідчать, що технологію глибинного шліфування слід впроваджувати у технологічні процеси замість операчій фрезерування, зовнішнвого протягування і традиційного шліфування.

Ключові слова: планетарна шліфувальна головка, глибинне шліфування, температура шліфування, підповерхневі шари деталі.

\section{Introduction}

Development of modern engineering, light and aviation industries is accompanied by the development of new structural, heat-resistant and wear-resistant steels and alloys with high strength properties. These materials are used in the production of critical parts such as blades, shafts, gears, providing high strength characteristics, thereby increasing the life of products operating at high temperatures with alternating cyclic loads. Processing such materials is very time consuming, and the use of blade processing methods is unproductive [1]. One of the ways to improve the efficiency of machining is the introduction of the technology of creep feed grinding. The process of creep feed grinding provides minimal damage to the treated surface, more productive compared to milling and pulling. It is also characterized by high cost-effectiveness compared to traditional processing methods. The technology of creep feed grinding allows to reduce the processing time, to increase the quality and accuracy of indicators of processed surfaces of parts. This is possible only on the basis of the description of the temperature state of the subsurface layers of the workpiece for the set processing modes, taking into account the geometrical parameters of the shape of the grinding wheels, as well as the kinematics of the process $[2,3]$. As the object of research, the process of creep feed grinding of parts of aircraft engines with difficult-to-work materials is selected. The aim of research is ensuring the quality parameters of the surfaces of parts of general engineering, light and aviation industry by the method of creep feed grinding.

\section{Methods of research}

Experimental studies of flat planetary grinding are carried out on a surface grinding machine of the Polish machinebuilding enterprise Jotes, model SPD 30-b [4], using an adapter, a planetary grinding head $(\mathrm{PGH})$ mounted on its spindle $[5,6]$.

PGH speed is adjusted in the range $n_{P G H}=0-800 \mathrm{rpm}$ by including the Lenze ESV752N04TXB (Germany) frequency converter into the main working motion motor circuit [7]. In the course of experimental studies on the PGH, $100 \times 20 \times 32$ abrasive wheels of a straight profile (SP) are installed with the following characteristics: 38A25BM28K35A3; 24A40M36K6. The diameter of the planetary head (together with abrasive circles) $D_{P G H}=350 \mathrm{~mm}$, the gear ratio $i=3.5$. The longitudinal feed of the part $\mathrm{S}_{\text {long }}$ is changed in the range of $0.1-0.8 \mathrm{~m} / \mathrm{min}$, and the grinding depth is $t=1-7 \mathrm{~mm}$. The treatments are carried out with the associated rotation of the PGH grinding wheels (Fig. 1) [8]. 


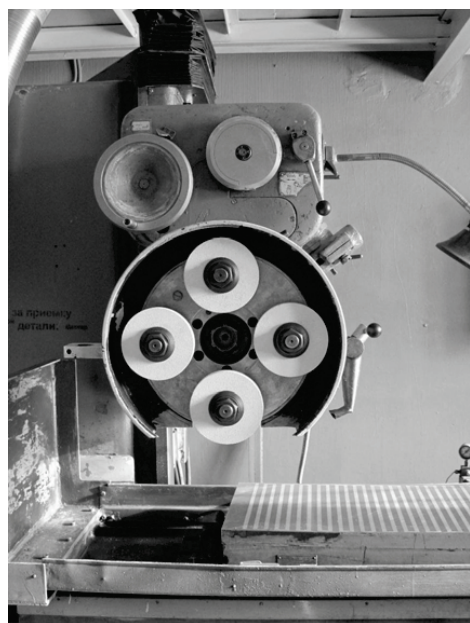

Fig. 1. General view of the planetary grinding head mounted on a surface grinding machine Jotes SPD-30b (Poland)

The temperature of the workpiece is measured in two ways - contact and contactless. The pyrometer CT 3M (Optris, Germany) carries out contactless measurement of the temperature on the surface of the grinding wheel in the cutting zone, as well as under the surface of the workpiece with a variable depth of measurements. Contact temperature measurements are carried out using thermocouples connected to the OBEH MBA8 meter (Russia), Fig. 2.
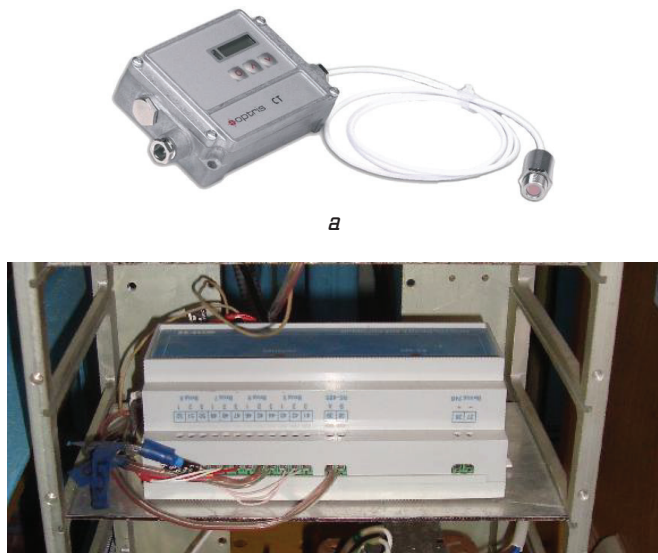

Fig. 2. Measuring complexes: $a$ - CT 3M pyrometer; $b$ - OBEH MBA8 meter

Thermocouples with a diameter of $1.8 \mathrm{~mm}$ of type $\mathrm{K}$ are connected with free ends to the inputs of the measuring device with the observance of polarity in order to avoid serious errors. The connection of the OBEH MBA 8 meter to the computer itself is carried out using the adapter RS-485 interface OBEH AC3 (Russia). Further, using the software supplied with the measuring device, thermocouples are surveyed and the results were then output.

As samples for carrying out experiments for the purpose of describing the preliminary preparation procedure, rectangular billets with dimensions of $85 \times 25 \times 25 \mathrm{~mm}$, made of tool die steel 4X5MФ1C according to GOST 5950-2000 [9] and hardness of 49-51 HRC are chosen. From the installation plane of the workpiece, blind holes are made, providing a hermocouple depth of $2 \mathrm{~mm}$ below the processed surface. For this, a vertical drilling machine 2ЧC112 СФ (Russia) and an electroerosive machine 4E723-01Ф1 (USSR) with a brass electrode RBS1D $180 \times 300$ are used. The result is a holes with a diameter of $1.8-2 \mathrm{~mm}$ with a radial rounding of the end face of the hole and a roughness $R_{a}=0.8 \mu \mathrm{m}$ (according to the passport of the machine). The thermocouple termination circuit is shown in Fig. 3.

According to the established methodology for conducting experiments, 18 samples are prepared. Thermocouples are mounted in each of them, as shown in Fig. 4.

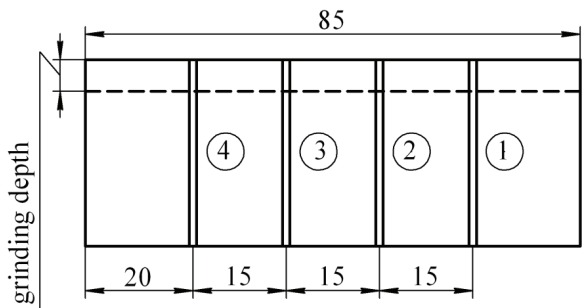

Fig. 3. Thermocouple laying scheme

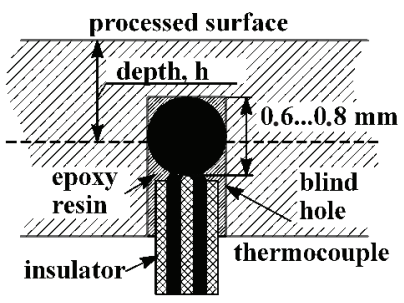

Fig. 4. Thermocouple laying

Experimental studies of temperature fields of workpieces from 4 X5МФ1C steel in their processing by SP circles $100 \times 20 \times 3238$ A25BM28K35A3, installed on PGH, are carried out with the following grinding process parameters:

- grinding depth $t$, mm: $0.5 ; 1.0 ; 1.5 ; 2.5$;

- rotation speed of circles $V_{c r}, \mathrm{~m} / \mathrm{s}: 12,16,20$;

- longitudinal feed $S_{L O N G}, \mathrm{~mm} / \mathrm{s}: 0.50 ; 0.75 ; 1,00 ; 1.50$;

- grinding width $B, \mathrm{~mm}: 20$;

- trimming of circles is carried out by single-point diamond pencil.

A $5 \%$ aqueous solution of $\mathrm{NaHCO}_{3}$ («soda water») is used as a process coolant.

\section{Research results and discussion}

As shown in the Table 1, the experimental values demonstrate good agreement with the results of theoretical thermal analysis. Thus, the correctness of the thermal model has been tested for the process of creep feed grinding with the use of a PGH by a large number of experiments. In addition, the results show that the measured temperature is higher, the higher the speed of the workpiece and the greater the depth of cut. However, the temperature of the workpiece is not reduced, but, conversely, increases slightly with increasing speed of the circle. Despite this, this effect of lowering the temperature of the workpiece does not apply when using higher circle speeds. The ratio of thermal distribution shows that increasing the speed of the circle more effectively increases the share of heat transfer to the tool and coolant. Grinding energy also increases with increasing speed of the circle, with the result that a greater amount of thermal energy will flow into the workpiece and the temperature will become higher. 
Results of experimental and theoretical studies

\begin{tabular}{|c|c|c|c|c|c|c|c|c|c|c|}
\hline \multirow{2}{*}{$\begin{array}{l}\text { № of } \\
\text { experi- } \\
\text { ment }\end{array}$} & \multicolumn{4}{|c|}{$\begin{array}{c}\text { Technological } \\
\text { processing modes }\end{array}$} & \multicolumn{2}{|c|}{$\begin{array}{l}\text { Heat flux, } \\
\text { W/mm }\end{array}$} & \multirow{2}{*}{$B_{W}$} & \multicolumn{3}{|c|}{$\begin{array}{c}\text { Workpiece } \\
\text { temperature, }{ }^{\circ}[\end{array}$} \\
\hline & $\begin{array}{ll}V_{C H} \\
\mathrm{~m} / \mathrm{s}\end{array}$ & $\begin{array}{l}D_{C H}, \\
\mathrm{~mm}\end{array}$ & \begin{tabular}{|c|}
$t_{s}$ \\
$\mathrm{~mm}$
\end{tabular} & $\begin{array}{l}S_{\text {LONG, }} \\
\mathrm{m} / \mathrm{min}\end{array}$ & $\square_{C R}$ & $\bigsqcup_{T O T}$ & & $\begin{array}{c}T_{E X P} \\
(2 \mathrm{~mm})\end{array}$ & $\begin{array}{c}T_{\text {THEOR }} \\
(2 \mathrm{~mm})\end{array}$ & $\begin{array}{c}T_{\text {THEOR }} \\
(0 \mathrm{~mm})\end{array}$ \\
\hline$\overline{1}$ & 20 & 80.2 & 1.50 & 0.200 & 6.48 & 7.15 & 320 & $160.9^{*}$ & 183.1 & 250.5 \\
\hline 2 & 20 & 79.6 & 1.50 & 0.075 & 6.42 & 6.24 & 0.310 & 72.5 & 74.2 & 86.0 \\
\hline 3 & 20 & 79.4 & 1.50 & 0.060 & \begin{tabular}{|l|l|}
6.34 \\
\end{tabular} & 5.28 & 0.292 & 69.5 & 38.5 & 79.1 \\
\hline 4 & 20 & 79.0 & 1.50 & 0.045 & 6.38 & 4.61 & 0.280 & 65.2 & 63.7 & 73.8 \\
\hline 5 & 20 & 78.6 & 1.50 & 0.030 & 6.24 & 4.20 & 0.272 & 59.5 & 1.8 & 69.4 \\
\hline 6 & 20 & 78.4 & 1.00 & 0.090 & 7.05 & 5.73 & 0.332 & 69.5 & 65.8 & 78.4 \\
\hline 7 & 20 & 78.2 & 1.00 & 0.075 & 7.14 & 4.87 & 0.326 & 63.5 & 1.0 & 70.8 \\
\hline 8 & 20 & 77.8 & 1.00 & 0.060 & 7.13 & \begin{tabular}{|l|}
4.26 \\
\end{tabular} & \begin{tabular}{|l|l|}
0.316 \\
\end{tabular} & 59.4 & 56.7 & 64.1 \\
\hline 9 & 20 & 77.4 & 1.00 & 0.045 & 7.03 & 3.79 & 0.296 & 55.5 & 52.9 & 60.7 \\
\hline 10 & 20 & 77.0 & 1.00 & 0.030 & 7.03 & 3.47 & 0.288 & 51.9 & 51.7 & 57.7 \\
\hline 11 & 16 & 76.8 & 2.50 & 0.090 & 4.97 & 6.17 & 0.311 & $230.9^{*}$ & 210.7 & 320.1 \\
\hline 12 & 16 & 76.6 & 2.00 & 0.060 & 5.40 & 5.27 & 0.328 & 77.2 & 78.6 & 88.0 \\
\hline 13 & 16 & 76.2 & 1.50 & 0.060 & 5.70 & 4.50 & 0.332 & 66.5 & 67.9 & 77.6 \\
\hline 14 & 16 & 75.8 & 1.00 & 0.060 & 6.47 & 3.96 & 0.340 & 56.8 & 57.4 & 65.8 \\
\hline 15 & 16 & 75.4 & 0.50 & 0.060 & 7.57 & 3.37 & 0.380 & 50.4 & 46.8 & 55.1 \\
\hline 16 & 12 & 62.8 & 1.50 & 0.060 & 5.01 & 4.06 & 0.377 & 67.6 & 66.9 & 77.3 \\
\hline 17 & 16 & 62.0 & 0.50 & 0.030 & - & - & - & $820.0^{*}$ & - & - \\
\hline 18 & 16 & 74.0 & 0.50 & 0.030 & 7.54 & 3.25 & 0.369 & 48.2 & 47.0 & 54.2 \\
\hline
\end{tabular}

Note: * - burn appearance

The grinding energy values $q_{\text {tot }}$ in the Table 1 are above the critical grinding energy values $q_{\text {crit }}$ for experiments No. 1 and No. 11. In addition, in both these cases, the maximum surface temperature of the workpiece $T_{\text {theor }}(0 \mathrm{~mm})$ is very close to the temperature of the bubble boiling point of the liquid. Burn of the workpiece does not occur at the beginning of the grinding process, but only after a certain length of movement of the grinding head. In addition, the transition from normal processing conditions to the burn formation is accompanied by a sudden (abrupt) increase in grinding force and a rapid increase in the temperature of the workpiece.

After this, burn on the surface of the workpiece is formed continuously. Let's note the conditions for the burn formation. For this, the vertical and horizontal component of the cutting force is determined by its average value. Determination of its value is performed for each discrete movement of the grinding wheel relative to the processed surface. As an example, let's take experiment No. 1, the beginning of the burn formation of the workpiece is thirty-eighth second of the grinding process. The calculation period of the average temperature values is from 16 to 32 seconds of the grinding process. Thus, the experimentally obtained temperature value at the second thermocouple at a depth of $2 \mathrm{~mm} T_{E X P}$ is decisive as the maximum measured temperature value. At this point in time, burn of the preform is not yet formed. Burn occurs at the time when the grinding wheel passes over the third thermocouple, even if it recorded a lower temperature than the second thermocouple.

As a result of the experiments performed for parts made of $4 \mathrm{X} 5 \mathrm{M} \Phi 1 \mathrm{C}$ steel, the adequacy of the thermal model is confirmed, which makes it possible to predict the temperature of the workpiece and has good consistency with the experimental data. Moreover, the signals of the measured grinding power and temperature can set the burn appearance of the workpiece. Experimental results show that the transition from machining conditions without burn to machining with burn is accompanied by a sharp increase in grinding power and a further increase in the temperature of the workpiece when the grinding energy formed during the experiment exceeds the critical energy. Thus, the burn occurrence of the workpiece can be predicted in order to prevent it.

\section{Conclusions}

According to the research results, it is found that the use of PGH for creep feed grinding of machine-building and aviation parts [10] of difficult-to-work, corrosion-resistant materials leads to a decrease in the energy-power indices of the process while simultaneously improving the surface cleanliness class:

- temperature in the contact zone is reduced to values at which there are no phase transformations in the surface layers of the workpiece: $60-90{ }^{\circ} \mathrm{C}$ (except for experiments No. 1, 11 and 17);

- there is an improvement in the physical and mechanical properties of the processed surface (the roughness of the processed surfaces is within $R_{a} 1.25-1.8 \mu \mathrm{m}$ ); - multiple well cubic boron nitride circles allow to force grinding mode without compromising the accuracy and quality of processing;

- greatly reduces the coolant consumption, up to its absence in the process. In addition, the requirements for coolant properties may be less critical;

- stability of abrasive wheels is increased (at least 2 times)

\section{References}

1. Research on surface integrity of grinding Inconel718 / Yao C. F. Jin Q. C., Huang X. C., Wu D. X., Ren J. X., Zhang D. H. // The International Journal of Advanced Manufacturing Technology. 2012. Vol. 65, Issue 5-8. P. 1019-1030. doi: http://doi.org/ $10.1007 / \mathrm{s} 00170-012-4236-7$

2. Creep feed grinding of $\gamma$-TiAl using single layer electroplated diamond superabrasive wheels / Hood R., Cooper P., Aspinwall D. K., Soo S. L., Lee D. S. // CIRP Journal of Manufacturing Science and Technology. 2015. Vol. 11. P. 36-44. doi: http://doi.org/10.1016/j.cirpj.2015.07.001

3. Bi X. F. Effects of Grinding Parameters on Creep Feed Grinding // Advanced Materials Research. 2013. Vol. 658. P. 255-258. doi: http://doi.org/10.4028/www.scientific.net/amr.658.255

4. Ploskoshlifoval'nyy stanok s gorizontal'noy os'yu vrashheniya Jotes SPD-30b: tekhn.-ekspluatats. dok. Fabryka szlifierek «PONAR-Lódz». Zaklad «Jotes», 1975. 226 p.

5. Surdu N. V. Povyshenie effektivnosti shlifovaniya trudnoobrabatyvaemykh materialov za schet usovershenstvovaniya kinematiki protsessov: PhD thesis. Kharkiv: Institut problem mashinostroeniya im. A. N. Podgornogo NAN Ukrainy, 2005. 241 p.

6. Sozdanie planetarnoy golovki dlya glubinnogo shlifovaniya trudnoobrabatyvaemykh materialov / Tarelin A. A., Surdu N. V., Telegin A. V., Fistik A. G. // Eastern-European Journal of Enterprise Technologies. 2009. Vol. 4, Issue 6 (40). P. 4-12. URL: http:// journals.uran.ua/eejet/article/view/22015/19522

7. Lenze SMVector - preobrazovatel' chastoty. URL: https://saa. su/Manual/Lenze/SMV_IP31_IP65(RUS).pdf

8. Kurin M. O. Doslidzhennia tekhnolohii planetarnoho hlybynnoho shlifuvannia ploskykh poverkhon detalei aviatsiinykh dvyhuniv: PhD thesis. Kharkiv: NAU im. M. Ye. Zhukovskoho «KhAI», 2011. 179 p.

9. Marochnik staley i splavov / ed. by Zubchenko A. S. Moscow: Mashinostroenie, 2003. 784 p.

10. Profil'noe glubinnoe shlifovanie zubchatykh koles / Eliseev Yu. S., Novikov V. S., Starkov V. K., Ryabtsev S. A. // Vestnik mashinostroeniya. 2001. Issue 1. P. 41-44.

Kalinichenko Nikolai, Department of Aircraft Engine Production Technologies, National Aerospace University H. E. Zhukovsky «Kharkiv Aviation Institute», Ukraine, e-mail: kharcraft@gmail.com, ORCID: http://orcid.org/0000-0002-8685-065X 